Article

\title{
The Location of Settled Diasporas in Nova Scotian Fiction
}

\author{
Miasol Eguíbar-Holgado $\mathbb{D}$ \\ Department of English, French and German Philology, University of Oviedo, 33011 Oviedo, Spain; \\ eguibarmiasol@uniovi.es
}

Received: 12 July 2020; Accepted: 31 August 2020; Published: 2 September 2020

\begin{abstract}
This article offers a comparative study between two novels by Nova Scotian writers: George and Rue (2006), by George Elliott Clarke, and No Great Mischief (2000), by Alistair MacLeod. The main purpose of this analysis is to transform some of the pervasive assumptions that dominate interpretations of diasporic ontologies. Most conceptual contexts of diaspora, constructed around the idea of a homeland that is located elsewhere, can only partially be applied to historically long-established communities. Clarke's and MacLeod's works emphasize "native" identity, the historical presence of Africans and Scots in Nova Scotia and their ensuing attachment to the (home)land. The novels illustrate how the hostland may be transformed into a homeland after centuries of settlement. The favoring of routes over roots of many current conceptualizations of the diaspora thus contravenes the foundations on which these groups construct a "native/diasporic" identity. However, in settler colonies such as Canada, identifying these groups as unequivocally native would imply the displacement of the legitimate Indigenous populations of these territories. A direct transformation from diaspora to indigenous subjectivity would entail the obliteration of a (however distant) history of migration, on the one hand, and the disavowal of Indigenous groups, on the other. For these reasons, new vocabulary needs to be developed that accurately comes to terms with this experience, which I propose to refer to as "settled diaspora." In settled diasporas, the notions of attachment to a local identity are reconciled with having distant points of origin. At the same time, there is conceptual room to accommodate claims of belonging that differ from those by Indigenous populations. Thus, the concept of the settled diaspora redresses critical restrictions in diaspora theory that prevent discourses of migration from being applied to spaces of settlement.
\end{abstract}

Keywords: settled diaspora; homeland; hostland; indigeneity

\section{Introduction}

This article is a comparative study between diasporic literatures of the African and Scottish traditions in the Canadian province of Nova Scotia. It focuses on contemporary fiction as the main object of analysis, following representational strategies and ontologies which, in connection to experiences of migration, displacement and settlement, offer a unique perspective on diasporic narratives. The key texts chosen for this study are George and Rue (Clarke 2006) by George Elliott Clarke from the African-Nova Scotian tradition; and from the Scottish-Nova Scotian, No Great Mischief (MacLeod 2000) by Alistair MacLeod. George Elliott Clarke is one of the most acclaimed Canadian writers, Toronto's Poet Laureate in 2012 and recipient of the Governor General's Award for Execution Poems in 2002, among other outstanding recognitions. As a seventh-generation black Canadian, his fiction, as well as his critical scholarship, focus on the recovery of the historical experience of blacks in Nova Scotia/Canada. His novel George and Rue is a narrative account of the lives of George and Rufus Hamilton, two brothers born in Nova Scotia, who were hanged for the murder of a taxi driver in New Brunswick, in 1949. Both historical and personal events compel Clarke to engage with this episode, as 
the protagonists were in fact his cousins. The narrative emphasizes the long-established genealogy of the Hamilton family, as they are described as belonging to a part of the black Nova Scotian population who arrived as slave refugees in the beginning of the nineteenth century. Clarke's is an inclusive narrative that adopts the stance of the invisible and silenced. Recuperating this fragment of history contributes to the (re)imagining of the black Canadian voice.

No Great Mischief engages closely with Scotland and its legacy. Alistair MacLeod was another renowned Canadian writer, Officer of the Order of Canada and recipient of the International Dublin Literary Award, among many others. He was born in Saskatchewan in 1936, but grew up in Cape Breton, Nova Scotia, with his Scots Canadian family. It is not coincidental to find such a strong connection to the Old Country in the novel. Cape Breton Island is one of the last Gaelic-Speaking areas in the world, and certainly one of the very few in North America. This island in the easternmost part of Nova Scotia is thus particular in that it has retained elements of Highland traditions, culture, and language, from the early settlements (in the eighteenth century) to the present. The influence of Scottish hereditary traditions and values permeates MacLeod's entire work. In No Great Mischief, he portrays, through the eyes of Alexander MacDonald, the history of clan Calum Ruadh, a history that spans a period of two hundred years, from the moment Alexander's ancestors leave Scotland bound for Canada to the present in Alexander's story. The novel opens with Alexander going to visit his older brother Calum in Toronto (both middle-aged men now), a point from which he starts the narration of his own life. It deals with the struggle to maintain alive a set of traditions and values (of Scottish origin) which do not seem to belong in the contemporary world, because their ontological space is gradually shrinking with each new generation. No Great Mischief therefore seems to be tinted with the element of nostalgia that characterized nineteenth-century colonial novels, which profoundly lamented the loss of the "mother country." There are aspects of the text, however, that situate it as a contemporary novel that seeks to explore and assert a specifically Canadian identity (as opposed to an identity anchored elsewhere).

The comparative analysis of these groups' writings emerged as an ambitious and rather broad research project to describe points of agreement and points of discrepancy between them, in their respective approaches to diasporic manifestations, in order to provide a nuanced and balanced perspective of the heterogeneous landscape of Nova Scotia's diasporas. A more exhaustive reading of the texts, however, revealed that in spite of the severe differences, especially in historical terms, between the Scottish and African diasporas, there were regional parallelisms of an emphasis on roots and attachment to the land that would cohere into the development of a new concept: the settled diaspora. While scholarship on diaspora is fairly recent and mostly connected to migration movements that took place in the twentieth century (in its second half, in many cases), Nova Scotia has been harboring diasporic groups since the eighteenth century. Historical coexistence of Indigenous, black and white groups (including British, with their internal ethnicities, Acadians, Germans and Irish, among others) has produced long-standing practices of exclusion and racism in the province: from the displacement and near annihilation and disenfranchisement of the Indigenous Mi'kmaq population, to the expulsion of Acadian settlers (of French descent), and segregation and marginalization of the black population. Colonial and postcolonial practices have regulated relationships among these groups. Racial hierarchies have been established, space management policies enforced and strategies of cultural promotion applied, so that uneven patterns of entitlement and dispossession have emerged throughout centuries of coexistence. As the region is ascribed a "naturally" Anglo-Celtic ${ }^{1}$ identity, groups like blacks are consistently read as aliens, and ironically, even Indigenous peoples are removed from its hegemonic center. Against this backdrop, it becomes essential to develop attentive definitions of

1 As I shall discuss below, Scotland occupies an ambivalent position within the British Empire. Because it is simultaneously expansive, yet internally displaced in relation to England, Scotland is seen as both participating in, benefitting from, and marginal to the British Empire. Although Celtic culture is negatively affected in its marginality, the province of Nova Scotia is nevertheless coded as Celtic in dominant cultural discourses. 
experiences that involve cultural displacement, indigeneity and belonging. In the (post)colonial Nova Scotian (and more broadly speaking, Canadian) context, questions of migration and settlement must be put in conversation with the presence of Indigenous peoples. This is even more pressing when dealing with the presence of black as well as white settlers. As critics have remarked, the struggle "over 'nativeness' necessitates the paradoxical neutralization of Indigeneity as a precondition for the settling of non-Indigenous racialized and ethnic groups" (Cornellier 2016, p. 79). A straightforward dialogue between elements of indigeneity, settlement and diaspora is further complicated when considering how the displacement of Indigenous populations by white settlers under colonial advancement has also produced what some view as Indigenous diasporas. Gregory Smithers points at the analogy between the displacement of some Indigenous populations and that experienced in traditional diasporas when he contends that, "[f]orced by the pressures of intertribal conflict and the exclusionary impulses of settler colonial regimes of power, indigenous individuals and groups strove to maintain a coherent sense of group identity by transporting, innovating, and adapting their concepts of land, kinship, spirituality, cultural self-representation, and so forth to new homelands and different mediums of communication" (Smithers 2014, p. 15). It is precisely the complex nature of these relationships that will call for the articulation of new forms of belonging, in which the concept of the settled diaspora plays an essential role. The main aim of this article is the location and definition of this innovative concept, through a close reading of the texts mentioned above.

\section{Diasporas, Homelands and Settled Diasporas}

Diaspora discourses have proliferated in the last three to four decades. The word "diaspora" was originally used to describe the Jewish exile and sojourns, written with a capitalized spelling (the Jewish Diaspora). However, recent appropriations of the term, metaphorical or not, may refer to a wide range of population scatterings, under various motivating circumstances (Tölölyan 1996). Deeply tied to globalizing phenomena (changing political conditions, technological, transportation and communication advances which have set the bases for unprecedented migration movements), a great part of diaspora studies concentrates on post-Second World War dispersals (Reis 2004, p. 46). One of the main problems that theories of diaspora present lies in their exploitability. The possibilities of the concept as a descriptive device are currently being overstretched: as Rogers Brubaker points out, "[i]f everyone is diasporic, then no one is distinctively so. The term loses its discriminating power-its ability to pick out phenomena, to make distinctions. The universalization of diaspora, paradoxically, means the disappearance of diaspora" (Brubaker 2005, p. 3). As a consequence, critics such as Robin Cohen (2008) have intended to reach a compromise between notions that cling on to the classic, Jewish diaspora experience and those which use the concept to address almost any kind of dispersal. One of his most significant conceptual contributions, what he calls his "most controversial departure from the prototypical Jewish diasporic tradition" $(2008$, p. 6), is the suggestion that, rather than exclusively originating under traumatic conditions, diasporas may also emerge as part of voluntary movements of migration. Even though migrating voluntarily does not necessarily imply the absence of trauma, there are many implications to this theoretical expansion: it affects the whole perception of the homeland, the process of detachment and/or maintenance of allegiances, as well as the identity of the group within the hostland's society.

While diaspora scholars may diverge in the delineation of some of the features that characterize diasporas, most theories coincide in the essential role of the homeland. Tölölyan emphasizes this link, when he asserts that "[d]iasporan communities maintain contact with the homeland when it persists in identifiable form. Lacking that, they exhibit a communal will to loyalty, keeping faith with a mythicized idea of the homeland" (Tölölyan 1996, p. 14). This last point is crucial, in that it acknowledges the existence of homelands which are not grounded in a given geographical space. The idea of a non-real homeland is perhaps best explored by Salman Rushdie in his collection of essays entitled Imaginary Homelands (Rushdie 1992). The diasporic condition of physical detachment from home implies a process of mental and narrative re-construction, even in cases where that home exists 
as an identifiable territory. The recreation of the homeland from the outside means that diasporic subjects "will not be capable of reclaiming precisely the thing that was lost; that we will, in short, create fictions, not actual cities or villages, but invisible ones, imaginary homelands" (Rushdie 1992, p. 10).

The inescapable presence of the ancestral/original homeland (as fundamental factor in the definition of the diaspora) may easily correlate to newly formed diasporas but becomes harder to retain as generations of diasporans succeed each other and reside in the hostland for hundreds of years. The same could be said for the emphasis that has been given to practices of mobility, such as Paul Gilroy's idea of "routes" as the defining metaphor of diasporas, instead of that of "roots," that would be more easily associated with native or indigenous experiences (Gilroy 1993). New concepts and a new vocabulary need to be developed in order to accurately portray the experiences and the cultural, social and political productions of these collectives. In this article, the concept of diaspora will be re-evaluated, not to further expand it or to create new subcategories, but to partially transform and reformulate it. The main focus of this study is, therefore, the creation and delimitation of the concept of "settled diasporas". It refers to these particular diasporic manifestations that, mainly due to their longevity, fall away from "diaspora" and "transnationalism" discourses, but whose claims to indigeneity also need to be problematized.

Preserving the idea of the homeland may be impossible in the generations following settlement. Although it would be very difficult to determine exactly how much time should pass until the homeland no longer holds a strong grip on diasporans' identities, it is certain that first-generation migrants are much closer to the "mother country" than third- or fourth-generation migrants. One distinctive feature of settled diasporas is, therefore, that they maintain loose relationships with the homeland. This means that it is harder to find in settled diasporas an active economic or emotional investment in its maintenance, and even connections with it may be sparse. Due to geographical and temporal distancing, not only are these connections neglected, but the constant desire for return is made materially impossible and altogether abandoned as a collective purpose or ultimate goal. This unconstrained relationship with the homeland can be observed in both the African and the Scottish diasporas in Nova Scotia, albeit in different terms and for different motives, as will be shown below.

The central role of the homeland is a quandary in the definition of the African diaspora. As Paul Gilroy and others propose, rather than attached to a fixed geo-political location, the African diaspora originates from a sense of collective distinctiveness, that may have been set in motion through forceful otherization "us/whites" vs. "them/black" in the hostland (Gilroy 1993). The African diaspora would thus cohere around cultural, historical and social bonds, rather than around the existence and preservation of a fixed physical homeland. This article proposes that some of the complex and diverse groups of African diasporas be analyzed under the self-contained notion of the settled diaspora, instead of conflating all these diasporic contexts into a separate category within the idea of diaspora. In settled diasporas, the ancestral homeland does not disappear completely; it is still the source of some cultural and social values and features that are incorporated into the lives of settled diasporans in one way or another. Moving on to the Scottish diaspora, it is easy to see that for many of its members, connections to the homeland are not direct and they rarely involve socio-political action and/or awareness. In this context, it becomes even clearer how allegiance to the hostland has replaced gradually and almost completely a close attachment to the homeland, to the point that it could not be said that Scots living today in the United States or Canada do not feel at home, or that they consider their homeland to be somewhere else. Scots-Canadian communities may, therefore, be described as settled diasporas, as groups in which there is only a lax or symbolic connection with the homeland.

Conceptually, settled diasporas are not a next step of, an improvement on, or an evolution from diasporas. This concept moves away from the study of originating causes of migration and focuses on conditions of settlement and the formation of new ontologies in a hostland that gradually becomes a homeland. It could be pointed out that settled diasporas are not in any way related to diasporas, to the necessary element of elsewhere, and that the objects of study are migrant collectives who gradually transform from foreigners into indigenous. Indeed, if much of what means to conform to a settled 
diaspora is a product of living in a place for an extended period of time, then the conclusion could be reached that these peoples eventually become indigenous. Clifford asks precisely the question "How long does it take to become 'indigenous'?" when distinguishing between diasporic and native identities, and goes on to mention that "it is clear that the claims to political legitimacy made by peoples who have inhabited a territory since before recorded history and those who arrived by steamboat or airplane will be founded on very different principles" (Clifford 1994, p. 309). At stake here is, on the one hand, the authority to claim indigeneity on the part of settled diasporans, and, on the other, the effects that such claims may have on Indigenous peoples. In Nova Scotia (and the broader context of Canada, as a settler colony), the land has already been inhabited for centuries by First Nations Peoples. Thus, this transformation from foreigner into indigenous is not straightforward and unproblematic. Indeed, this problematic belonging means the settled diaspora is an essential tool to identify these groups precisely as belonging "problematically." Stating that Scots and Africans who have inhabited Nova Scotia for generations become simply Canadians (or native) implies further displacement and erasure of Indigenous groups. The concept of the settled diaspora is thus necessary to set apart these divergent experiences.

Historically, relationships between Scots and First Nations Peoples on the one hand, and Africans and First Nations on the other, differ significantly. Needless to say, Scots were among the white pioneers who "conquered" the land and established settlements in the colonies, which means that from the start their migration movements involved the purpose of creating new homelands, of dominating and exploiting the supposedly virgin, empty territory and molding it into communities that initially followed imperial planning but which would eventually develop into independent societies. In this process, the obliteration of Indigenous peoples results in "the trauma and anxieties of (un)belonging that haunt settler culture" (Herrero 2014, p. 89). The settler subject is trapped between two contradictory planes: settlement projects often involve unmistakable acts of violence; there is, at the same time, a consistent disavowal of that violence, for its acknowledgement threatens the legitimacy of the imperial enterprise.

It is hard to underestimate the role of Scottish colonizers in the shaping of what today is Canada. By the end of the eighteenth century, the greatest commercial company in British North America, the Hudson Bay Company, was chiefly run by Scots, originating mainly from the Orkney Islands. The North West Company, the other outstanding Canadian trading firm, was from its conception equally managed by Highland Scots. By the time these two companies merged in 1821, Canadian trade and resource exploitation had become almost exclusively a Scottish monopoly (Devine 2011, pp. 15-16). It is interesting, however, that the relationship between England and Scotland is often compared to that between a colonizing center and its colony. As critics have noted (see Rodríguez 2007, p. 67), the application of postcolonial perspectives to the definition of Scottish socio-cultural identities has been widely contested, especially when considering that Scotland was an active participant in the British Empire colonial project. However, critics such as Berthold Schoene argue that, when addressing the British Empire, it is necessary to make distinctions within what constitutes the geopolitical entity called Britain, since "many Welsh, Irish and Scottish people perceive themselves as citizens of colonized nations which neither represent fully equal constituents of Great Britain nor independent member states of the Commonwealth" (Schoene 1995, p. 108). Arguably, Scotland maintains a marginal position in relation to England, both in political and in cultural terms. Historically, Highland cultural practices, the clan system and the Gaelic language were suppressed for decades after the eighteenth-century Jacobite risings, a harsh period that culminated in the violent Highland Clearances ${ }^{2}$. Celts were considered an

2 The Highland Clearances took place from the mid-eighteenth century to the mid-nineteenth century. It was a process of agrarian transformation through which people were expelled from the lands they worked and lived in (but which they did not possess) by the landowners, in order to make way for sheep. Cottars (as the workers were known) were thus cleared from the lands they subsisted on so that their labor could be replaced by the more profitable activity of sheep breeding. This development combined with increases in population, which prompted migration, sometimes by forceful means. 
inferior and barbaric race, and even when their presence was no longer deemed a threat to English political projects, still Celtic traditions were either ridiculed from intellectual elites or transformed, in a process known as "Balmoralization," into romanticized commodities during the nineteenth century. This ambivalence permeates the novel: the main characters are Highlanders and have experienced internal marginalization from a British dominant power. Despite this internal ambivalence, it remains clear that the effects of colonization on First Nations Peoples, which continue to the present, are devastating and that talking about a Scottish-Canadian indigeneity, however ambivalent, involves the further disavowal of First Nations Peoples.

Relationships between blacks and First Nations Peoples are even more difficult to pin down, not least because these connections are relatively under-researched. Moreover, the role of black settlers in colonizing Canada is definitely not the same as that of white settlers. Nevertheless, assuming a black-Canadian native identity in the face of an Indigenous presence is also controversial. At this point, it is useful to turn to George Elliott Clarke's own project of documenting and establishing an African legacy in Nova Scotia. His initiative to inventory and promote the cultural presence of blacks in the region leads him to gather different works that attest to this presence, in an anthology entitled Fire on the Water (Clarke 1991). Clarke's scope is decidedly historical: being a seventh-generation black Nova Scotian himself, he resorts to this long-standing tradition of Africans to vindicate their rights and their position within the historical and cultural panorama. It is on these bases that he coins the term of Africadia, which refers to a sociocultural cosmos of black communities in Nova Scotia descending from black Loyalist and refugee groups (Clarke 2002, p. 107). Clarke's strategy of incorporating the Africadian cultural panorama into the wide African diaspora and into the world of Canadian literature implies the adoption of an indigenous stance, which has been contested from diverse sources. One of the main objections has been formulated by Paula Madden, who opposes this identification of blacks as indigenous to Nova Scotia on the grounds of the displacement and disenfranchisement that this affirmation entails for the "true" native groups of the region, primarily the Mi'kmaq peoples. Madden sustains that "Clarke's attention to genealogy, place and his naming of some Black Canadians as indigenous, asserts a claim to the nation that is positioned as more authentic," and adds that "[ $\mathrm{t}]$ his claim to indigeneity accomplishes the same erasure of First Nations' primary claim to this land as does Euro-Canadians' refusal to acknowledge their 'elsewhere'-in other words their origins in foreign lands" (Madden 2009, p. 34). While pointing out the need to recognize the downfalls of inadvertent colonialism, Madden's challenges can be dismantled in two ways. On the one hand, it is problematic to sustain that white settlers' policies of appropriation and exclusion operate at the same level as black land settlement. As she admits herself, "both groups [Mi'kmaqs and blacks] were, from the beginning of their contact with whites, subjected to unequal treatment and racial violence" (p. 63). Blacks' access to the land of Nova Scotia was not a direct act of dispossession. The circumstances surrounding their migration and settlement are connected to traumatic episodes of abduction, dislocation, violence and abuse. Therefore, their eventual escape to Nova Scotia cannot be read in the same terms as the imperial projects of territorial expansion and civilizing betterment of white settlers, especially those from the upper and middle classes. Indeed, Chickasaw scholar Jodi Byrd uses the term "arrivant" 3 "to signify those people forced into the Americas through the violence of European and Anglo-American colonialism and imperialism around the globe" and set them apart from white settlers (Byrd 2011, p. xix). This historical background complicates any direct identification between black and white settlers.

On the other hand, Clarke's own approach to the First Nations Peoples of Nova Scotia partly defuses tensions between black and Indigenous relationships vis-à-vis a Canadian homeland. Aside from ontological connections that align First Nations and black groups together as a result of similar

3 While this concept (which Byrd borrows from Caribbean poet Kamau Brathwaite) is certainly useful in describing more transnational experiences, it still falls short to emphasize long-term settlement and attachment to the new land, as is my main intention here. 
experiences of discrimination and social restrictions in this region, as Clarke declares, there exist important biological ties between both races. He affirms that "[m]any Africadians-if not most-are Métis; that is to say, mixed with First Nations peoples, eminently—but not only—the Mi'kmaq" (Clarke 2012, p. 401). This is a largely unexplored domain, one that is only recently starting to gain visibility. One of the reasons for the opacity surrounding Mi'kmaq and black creolization is the fact that many black families concealed the presence of Indigenous relatives because, as Dorothy Mills-Proctor has put it, "[i]t's bad enough being black" (Mills-Proctor 2010, p. 55). Black-Indigenous alliances are thus obscured by practices of colonialism and processes of racialization that internally affect how othered groups regard each other. Recently, critics are advocating for investing in such potential alliances. In this vein, Yellowknives Dene scholar Glen Coulthard writes that the ongoing practice of discrimination in settler colonies:

demands that we continue to remain open to, if not actively seek out and establish, relations of solidarity and networks of trade and mutual aid with national and transnational communities and organizations that are also struggling against the imposed effects of globalized capital, including other Indigenous nations and national confederacies; urban Indigenous people and organizations; the labor, women's, GBLTQ2S (gay, bisexual, lesbian, trans, queer, and two-spirit), and environmental movements; and, of course, those racial and ethnic communities that find themselves subject to their own distinct forms of economic, social, and cultural marginalization. (Coulthard 2014, p. 173)

This is not to affirm that black and Indigenous relationships to colonial regimes should be understood as identical or that their struggles follow the same patterns and goals. Whilst analyzing these differences falls beyond the scope of this paper, critics have observed that there are indeed many disparities between Indigenous and black cultural and socio-political concerns, resulting in processes of self-definition that at times are even antagonistic (see Coleman 2016, p. 62; Amadahy and Lawrence 2009 , p. 119). Bearing this in mind, it is necessary to recognize how claims to Canada as a homeland differ when dealing with underprivileged groups such as black-Canadians.

Settled diasporas do draw on native and indigenous premises in that attachment to land and sentiments of belonging are similar to those displayed by native populations. These claims need to be carefully assessed, as they may incur in the erasure of legitimate Indigenous belonging, especially when made from a white settler perspective. An ongoing history of displacement (physical, cultural and psychological) of Indigenous peoples in Canada necessarily means that "the land" is articulated differently by these groups. The term is intimately related to past and current struggles for recognition and self-determination, a political and ontological implication that is obviously absent from (settled) diasporic experiences. Coulthard points out three interrelated meanings of "land" when used in struggles against colonialism: "land-as-resource central to our material survival; land-as-identity, as constitutive of who we are as a people; and land-as-relationship" (Coulthard 2014, p. 62). These referents escape the mere attachment that results from extended inhabitation, which diasporans and their descendants may eventually develop. Equally, Taiaiake Alfred (Kanien'kehá:ka) contends that "the crisis of dependency we face, which is defined in psychological and spiritual terms in addition to economic terms, requires a restoration of a relationship, on spiritual, psychological and physical terms, between indigenous people and their land" (Alfred 2015, p. 7). Thus understood, for Indigenous populations, the land can be read as a signifier that connects to the colonial experience (both before and after moments of contact) in ways that do not apply to "newcomers," no matter how far back in history their roots go. As these points of tension emerge, it becomes necessary to emphasize historical specificities in the construction of homelands by different groups. The concept of settled diaspora precisely enables delineating these differences: while the prolonged presence of settled diasporans in the land may lead to regarding the hostland as a homeland, their experiences cannot be unequivocally aligned to those of the Indigenous populations. The homeland constructed by the settled diaspora calls attention to the undeniable emotional attachments and material realities that emerge from inhabiting a place for generations. However, in establishing the settled diasporic experience as distinct from the 
Indigenous experience, the term avoids incurring in colonial discourses "where the land had to be physically and psychically emptied of its prior inhabitants and refilled with newly arrived 'natives' who compete for subjectivity within the emptied referent" (Byrd 2011, p. 69). "Settled diaspora" is an apparent oxymoron in which both components are equally important. Whilst the first term alludes to settlement extended in time, the second signals the history of migration behind these groups. Thus, it is not possible to disregard the diasporic dimensions of settled diasporic subjects. Migration and its history form part of their genealogy and coming from elsewhere means that traces of that original culture, religion, language, etc. remain and influence their development, even if it is in a more moderate manner than in traditional diasporas. It could be said that settled diasporans have seen the "homing desire" (Brah 1996, p. 180) fulfilled, by creating new homelands to which they problematically belong, while maintaining at the same time tokens and traces of their former homeland. The concept of the settled diaspora, then, charts the singular process by which diasporic groups disengage from an ancestral homeland and translate forms of emotional and tangible identification from that ancestral homeland into the hostland. Yet, settled diasporas articulate the "new" homeland in ways that should not be read as more authentic or legitimate than Indigenous articulations. The concept signals the necessary distinctiveness of both approaches, so as to avoid claims to sovereignty or hierarchies that would further suppress Indigenous authority.

\section{The African Settled Diaspora and Questions of (Un)Belonging}

Brah describes home as "the lived experience of a locality. Its sounds and smells, its heat and dust, balmy summer evenings, or the excitement of the first snowfall, shivering winter evenings, sombre grey skies in the middle of the day [ ... ] all this, as mediated by the historically specific everyday of social relations" (Brah 1996, p. 192; see also Tuan 1977, pp. 159, 185). As the protagonists of George and Rue are part of a largely rural community, there are passages in the novel in which direct contact with the land, or "the lived experience of a locality," can be observed. This is especially so in relation to the character of George, who becomes a farmer early in his life, an activity that shapes his identity: "While Rue had been in the music field, sort of, Georgie was in the cornfield. Rue beat on a banged-up piano; Georgie beat on two broken-down mules. Out of school now three years, and aged fourteen, of the two brothers, he was truly the "country" one: even his name was royally agrarian" (p. 42). Episodes showing George's farming activities portray more peaceful and idyllic representations of place and landscape. These representations are comparable to the frequent pastoral descriptions to be found in classical Maritime fiction (Keefer 1987, p. 187), especially when contrasted to those of the raw and harsh domestic space. Thus, in this natural, rural context, it is possible to encounter pictures such as the following: "The fields about Three Mile Plains and Hants County flowered pure clover and strawberries. Apples, blackberries, and raspberries could be gobbled down along the railway tracks. In the backwoods, the maple leaves used to tickle and harass him, lewdly" (p. 43). Even George's own body is gradually attuned to the tasks required by this environment: "The work was tough; his muscles got to be damned enormous. His hands were bad-ass carpenters, ingenious mechanics. [ ... ] He hauled hard against horses but looked just like a mule" (p. 43). Later, following their parents' deaths, "Georgie left Three Mile Plains but chose to stay in Windsor because he liked country life" (p. 70). The narrator reinforces the association of George and working the land with phrases like "[f]arming was natural for Georgie" (p. 70); it evokes an organic occupation of space, a practice that suggests a physical as well as emotional investment in the environmental surroundings; it is in fact a place in which "[h]e'd found Paradise" (p. 71).

Despite these more benign passages, the novel contains few instances in which Nova Scotia or the Maritimes ${ }^{4}$ are associated, explicitly or implicitly, to the idea of the homeland. George's temporary

4 The region of the Maritimes comprises the three Atlantic provinces of New Brunswick, Nova Scotia and Prince Edward Island. Although regionalism is one of the most widely used mechanisms of political, economic and cultural management 
achievement of an honest work that fulfils him, his brief periods of land-working, are some of the few occasions in which a character from the novel does feel fully integrated in society. Even these are eventually negated when his employer refuses to pay George for his work, and after complaining and taking away some tools as retribution, he is accused of robbery and briefly imprisoned, which results in George's stigmatization in his community (p. 99). Although one of the earlier lines of the novel states that the boys' father was "the third-generation to call Three Mile Plains home" (p. 10, emphasis added), the alienation that the characters feel from their social environments for most of the story is symptomatic of the experiences of unbelonging that characterize many diasporic groups.

In terms of settled diasporas, the construction of an imagined community does not mean that belonging may not be compromised by racist practices in the hostland. As Clarke informs "[f]or Africadians, Nova Scotia was a virtual dystopia. They not only lived an epic indigence, they also suffered ramshackle, poorly staffed schools - when they had any at all" (Clarke 2002, p. 111). The poverty he alludes to in these lines is that represented in the novel and this dystopia is certainly George and $R u e^{\prime}$ s Nova Scotia. However, rather than being portrayed as the means to cut the attachment to the land, this dystopia is presented as part of the long and complex history of blacks in the region. Black communities suffered from systematic abuse, marginalization and social repression. Yet, these factors are not seen as reasons for abandoning the idea of an indigenous identity; on the contrary, despite these obstacles, extended settlement within this land permits such identity to be constructed.

Clarke utilizes different mechanisms to make this belonging effective. First of all, the novel attests to Clarke's own racial métissage (alluded to earlier), which extends to his own family and therefore to the Hamilton brothers (both real and fictional). In one of the final sections of the book, entitled "Verdict" and signed by the writer, he includes a paragraph where this union is acknowledged:

Though repelled by the Hamiltons' crime, I embrace them as my kin. They were born where I was born-in the Africadian settlement of Three Mile Plains, Nova Scotia-and George Hamilton and I were named for the same gentleman, his grandfather and my great-grandfather, George Johnson. (In naming me as she did, my mother salvaged the memory of that perished cousin - and recuperated the regal name of her grandfather.) Too, the Hamiltons were-like so many of us from the Three Mile Plains, Five Mile Plains, Windsor Plains (all the same community, really)—part Mi'kmaq and part African. (p. 219)

This paragraph does not only incorporate the Mi'kmaq presence in the Africadian community, which Clarke embraces, but it also alludes to the relation between the protagonists and the writer, and their intricate stories and histories as part of the cultural landscape of Nova Scotia. The work of fiction proper further integrates this combination. In this passage, the narrator offers a glimpse at the uncertain genetic history of Africadians and how it translates into physical traits: "The Plains people had since mixed with the Mi'kmaq, but only a few ancients knew exactly with whom and when. The results were splendid, though. These saltwater, brass-ankle Negroes had bulbous noses, sharp black eyes, curly and partly straight hair, and skin tones running from deep molasses brown-black to maple sugar cream, auburn copper to red-iron, orange, and to blue" (pp. 14-15). These body variations and markers of mixed-race ancestry are described as a rich ancestry of beautiful complexions; however, it is precisely these signifiers which, in contact with white groups, otherize and marginalize Africadians. Thus, when George tries to find a job in Halifax, he is rejected because "nobody wanted his malt, half-Injun face on their payroll" (p. 83). In choosing to acknowledge and identify with his Mi'kmaq ancestry, Clarke delves into a profound history of discrimination.

in Canada, the conceptual bases as to what exactly constitutes a region are not clearcut and they very much depend on the context in which this entity is evoked. This flexibility is reflected in the ways the two authors compared in this study mediate regionalism: Clarke often articulates Nova Scotia as Africadia, whereas MacLeod mostly focuses on the island of Cape Breton. 
Considering that black communities are threatened by discourses that emphasize and insist on their otherness, there is a necessary negotiation of the tensions of living in a space that negates their integration and the desire for integration itself. Clarke says that "[a]nother point to make about the canon is that it is our canon too. Even though it was imposed on us, it still belongs to us. I am told that I have to accept these writers as great writers, and that, in terms of English poetry, these are the models I have to use, but perhaps we can take these models and blacken them" (Compton and Clarke 1998, pp. 141-42). Thus, the cultural de-centralization of Africadian literature is twofold: it refers to their alienation from Canadian archetypes which are, in turn, placed in the periphery of an English canon. Clarke's contestation of the position of black culture in Nova Scotia, twice removed from a formal center, is to appropriate, rather than reject, these impositions. It must be emphasized that this appropriation is not a mere act of mimicry: it entails challenging and transformation, and the inclusion of the imprint of black culture, that is, "blackening" the canon. A passage in the novel which describes the protagonist's father's affair with a white woman named Purity reflects this translation of cultures, as their sexual rapport is described through Shakespearian allusions brought to a rural Nova Scotian context: "The every-Friday-night Asa-Purity duo was an importation of Othello-and-Desdemona Venice to Windsor-on-the-Avon" (p. 32). Their interracial relationship is compared in dramatic terms to that of Shakespeare's characters; the town of Windsor, which is traversed by a river aptly named "Avon", works thus as a double referent for the geographical context of the original play, Venice, and for Shakespeare's native town, Stratford-upon-Avon. This creative re-conversion of cultural referents affects also the apparent solidity of geographical distributions. As Alexander MacLeod puts it "[i]n his always pastoral, green world of Africadia, the fixed facts of Nova Scotian geography become more flexible: Weymouth Falls can turn into Whylah Falls, and Digby County can change its name to Jarvis County. Beatrice Chancy can come from Italy and be relocated to the Annapolis Valley in 1801" (MacLeod 2008, p. 109).

This background allows the reading of George and Rue under a different light, one in which the racist society in which the characters struggle for survival is not represented exclusively as the antagonistic hostland that excludes migrant groups from its borders. The degree of complexity of this text implies the confluence of a discriminatory space with a space of belonging for Africadian peoples. This leads to negotiation strategies such as the politicizing of place naming, an identification with Indigenous populations, the incorporation of cultural elements from the mainstream domain but also an obstinate assertion of the black presence in the history of Nova Scotia. Like Fire on the Water, Whylah Falls and Beatrice Chancy, George and Rue constitutes one more layer in the cultural sediments that allow the reconstruction of different episodes of black Nova Scotian history. There are various reasons for the choice of this particular aspect of history, that is, the murder perpetrated by the brothers and their subsequent execution. On the one hand, the brothers were Clarke's relatives, and so his "desire to meditate on the fate of my kin" (Kyser and Clarke 2007, p. 868) comes from a personal drive. On the other hand, there is an urgency to disclose the impact of black communities on white societies (and vice versa) in this region. Because of the insistence on the centrality of black histories in the United States and the concomitant obscurity of similar experiences of discrimination, crime and violence in Canada, the allusion to this atrocious murder achieves two goals: to highlight the presence of black groups in Nova Scotia (and therefore Canada) and to denounce the deplorable living conditions of those groups.

While the novel does not exculpate the brothers from their deeds, for which Clarke acknowledges they received their sentence, he also states that "there remained socio-political attitudes, respecting 'Coloureds' in the Maritimes, in the 1940s and earlier, that merited examination, especially given that these attitudes helped to imprison black people in illiteracy, poverty, and unemployment (all excellent conditions for creating criminals and killers)" (Kyser and Clarke 2007, pp. 868-69). The regulation of space in racist terms as well as the discriminatory mindsets of white societies in Nova Scotia result in the characters' self-definition as outcasts: “Joygee, we is just thieves, pure thieves. We steal firewood, chickens, clothes off clotheslines, even fools' bad ideas" (p. 104). Even though George responds by reminding him that he has been able to support his family through hard work, Rufus insists on 
these readings of themselves, imposed by the readings of black communities established from the outside, abounding in derogatory and marginalizing signifiers. This is far from any concept of an idyllic homeland. However, the ultimate purpose of the novel is to portray these events as part of an ongoing genealogy present in the region since the eighteenth century. It is the historical roots, familial connections to the also dispossessed Mi'kmaq communities, and troublesome connections to place that this story emphasizes, a feeling of belonging articulated through pain and struggle.

\section{The Scots Settled Diaspora: From Scotland to Cape Breton}

There are several differences between the ways Clarke's and MacLeod's novels engage with both the ancestral homeland and the "new" homeland. Firstly, the ancestral homeland is not clearly demarcated in territorial terms for the protagonists in George and Rue. This diverges from No Great Mischief, where Scotland is distinctly localized as the ancestral homeland, and where Scottish culture and history are continually evoked. Different dimensions of the characters' lives, in individual and collective terms, are influenced by cultural and biological ancestral inheritances. However, the novel also contains textual evidence to demonstrate that Alexander and his family are not "strangers from elsewhere" (Zhang 2000, p. 126) and are not struggling to be integrated into a hostile society (as was often the case for the characters in George and Rue). Cape Breton is a homeland for these characters, a place where they do not feel alienated. This section explores passages in the novel that, implicitly or explicitly, attest to these affirmations, and the implications of such affirmations in the (post)colonial context of Canada.

Also in contrast to George and Rue, several episodes in No Great Mischief explicitly refer to Nova Scotia, and more specifically Cape Breton Island, as "home." This may well reflect the fact that official narratives of the region easily accommodate a Scottish identity and reject the presence of blacks in historical and cultural terms. One example of this direct identification is a passage when Alexander, together with both his grandfathers and his grandmother, are going back to Cape Breton after his graduation day in Halifax. The narrator is a witness to Grandpa's euphoria: "We crossed the Canso Causeway. When the front wheels of the car touched Cape Breton, Grandpa said, 'Thank Christ to be home again. Nothing bad can happen to us now.'/We still had an hour's drive or perhaps more along the coast, but it was obvious that Grandpa already considered himself in 'God's country,' or 'in our own country,' as he called it" (p. 108). Three elements may be emphasized from this excerpt: one is the rendition that Grandpa makes of Cape Breton as a safe place. Then, it is notable how Grandpa refers to Cape Breton as "our" country, the use of the possessive indicating a strong and exclusivist relationship with the land, one of the most frequently used mechanisms to express how the location of individual identity is perceived with respect to the world (Tuan 1977, pp. 149-50). Finally, a very localized position of the homeland can be detected, since the characters had been driving across Nova Scotia for the whole trip, but it is not until they crossed the causeway that they feel the relief of returning home. However, as pointed out earlier, a direct identification between First Nations Peoples' territories and "home" involves the displacement and disenfranchisement of those Indigenous populations. This necessarily problematizes any such direct appropriation of land.

There is little mention of Indigenous peoples in this novel, which again contrasts with allusions to the Mi'kmaq tribe in George and Rue, and with Clarke's own awareness of and investment in narratives about the shared history and ethnic mixing between blacks and Mi'kmaq. On one occasion, when retelling the story of his ancestors' migration, Alexander mentions that "[w]hen the boat landed on the gravelled strand, the cousins who had written the Gaelic letter and the Micmacs who were at home 'in the land of trees' helped them ashore and continued to help them through the first long winter" (p. 23). Here, the Mi'kmaqs are defined as the real Indigenous peoples whose home is Nova Scotia, in contrast to the Scottish newcomers, and there is no conflict between both groups, rather, harmony and comradeship can be read as they cooperate in the settler advancement process. This portrayal obscures the violence and appropriation of land and the erasure of Indigenous culture that accompanied settler projects and it is difficult to determine whether this passage would have a plausible historical 
foundation. Previously in this article, I have argued how Celtic ethnicity was preyed upon and forced to a process of anglicization with Britain's internal colonialism. Based on that distinction, affinities between Highlanders and Indigenous peoples are at times evoked in accounts of early appropriation and settlement of American territories. According to Colin Calloway, "having been colonized and 'civilized' themselves, Highland Scots sometimes identified and sympathized with Indian people they saw going through the kind of hard experiences they or their parents had suffered". Yet, he continues, "Highland traders, soldiers, and settlers often displayed the same prejudices, sentiments, and behavior as other European traders, soldiers and settlers when dealing with Indians, and Scots sometimes took on the role of colonizing and civilizing Indians with zeal" (Calloway 2008, pp. 17-18). In the particular context of Nova Scotia, it seems that there was at first a generally cooperative environment between the Mi'kmaq population and the French Acadians and later the early British settlers (Poliandri 2011, p. 199). Yet, British colonization by the time the first significant Scottish settlements took place in the region (end of the eighteenth and beginning of the nineteenth centuries) was gradually causing the decimation of the Mi'kmaq population (see Reid 2009). In one other occasion, the narrator in the novel briefly reflects on the current status of First Nations Peoples in Canada: "In Kingston Penitentiary, Calum said, a disproportionate number of the prisoners were from the native population. In many cases they did not fully understand the language of those to whom they were entrusted or condemned. They would hang their dreamcatchers in the windows of their cells, he said. [ ... ] It was the only thing he said about his years of incarceration" (p. 254). This excerpt does allude to an implicit situation of injustice, disenfranchisement and out of placeness, although the narrator does not identify any liability on the part of the white group to which he belongs. The Highland-Scottish ancestry present in this novel confers a degree of ambiguity to the settlers and their descendants, as well their role in imperial enterprises. The novel fails to directly align whiteness with the oppressor, and this comes in part from the self-identification of the characters with historically marginalized and dispossessed sectors of the Scottish society. In doing so, and especially in failing to deal more directly with Indigenous populations in a narrative so closely connected to the land, identity and belonging, the novel might be accused of neglecting "both the victimization Scots imposed on others and the power that the Romantic image of the Highland Scot wields in contemporary Nova Scotia" (Vance 2005, p. 170). Reading the protagonists of No Great Mischief as settled diasporans and thus placing them as belonging problematically in Nova Scotia helps to address these tensions.

Apart from appealing to ethnic differentiation, there are other ways in which the characters disengage themselves from a dominant or mainstream society (and could thus be said to belong problematically) and this is mostly in terms of class differentiation. The fictional lives of Alexander's brothers provide a small-scale embodiment of how intersections of class regulate belonging. Calum and his brothers live in isolation, on the very literal margins of society. Alexander describes their domestic surroundings: "For a long time in the house where my brothers lived, there was neither plumbing nor electricity, and heat came from two stoves filled with wood they hauled with their horses from the shore" (p. 59). The following words emphasize the distance between Alexander's and his independent brothers' lifestyles: "they never paid attention to Canada's Food Guide or to brushing their teeth before and after meals or to changing into clean pyjamas before going to bed. And at their house the bathroom was a bucket" (p. 61). They were never educated at school and, when they grew up, they worked in the mines for most of their adult lives; when the industry collapsed, however, they were forced to abandon Cape Breton. In the present time of the novel, Calum is described as a destitute man, an eccentric outcast. Alexander, on the other hand, as well as their sister, Catherine, "the 'lucky, unlucky' children" (p. 62), had the opportunity to receive a proper education.

The disparity of Alexander's and Catherine's place in society is marked by the physical spaces they occupy, which is reflected in the contexts in which they are usually portrayed together, repeatedly and almost obsessively referred to as Catherine's "modern house in Calgary" (pp. 90, 151, 153, 209). This intentionally emphasizes the "modern" as opposed to the traditional and outdated community from which they come. The different circumstances of their lives have given them the opportunity 
to leave Nova Scotia in search for more cosmopolitan and wealthy lifestyles, whereas Calum, who stays in the region, sees his life dramatically affected by its industrial recession and the disappearance of his profession, which constitutes an exploration of "the individual, human implications of social and economic collapse" (Hiscock 2000, p. 59). Calum (and only to a lesser extent the other brothers, as their identities are not so clearly discerned in the novel) embodies the epitome of a Nova Scotian working class whose existence is threatened and marginalized by the capital practices and modern society which Alexander and Catherine inhabit.

Significantly, one of the most relevant parts of the novel as regards the association between Cape Breton and a homeland is to be found in its last pages, and this is connected to the character of Calum. In the final moments of his life, Calum calls Alexander from Toronto saying that "It's time" (p. 256). He drives him to Cape Breton, and the instant the car arrives Calum dies. This could be read as the ultimate return home, voluntarily going back to the place of origins and postponing death, waiting to be there in order to complete the most essential life cycle. Once again, the description of the landscape and the surroundings, coupled with memories that are triggered by their return, suggests a deep bond with the island of their childhood: "I recognize all the familiar landmarks, although it is dark and there are mountains of snow. Here is the place where Grandpa threw the top of his whisky bottle out the window the day we were returning from my graduation. The day the red-haired Alexander MacDonald was killed, although we did not know it then" (p. 261). When dealing with MacLeod's stories, Jane Urquhart aligns them in a broader Canadian context by saying that

We Canadians are, after all, a nation composed of people longing for a variety of abandoned homelands and the tribes that inhabited them, whether these be the distant homelands of our recent immigrants, the abducted homelands of our native peoples, the rural homelands vacated by the post-war migrations to the cities, or the various European or Asian homelands left behind by our earliest settlers. All of us have been touched in some way or another by this loss of landscape and of kin, and all of us are moved by the sometimes unidentifiable sorrow that accompanies such a loss. (Urquhart 2001, pp. 37-38)

The characters of this novel are highly influenced by and stubbornly maintain certain traditions despite globalizing circumstances that threaten with cultural loss, but they have a clear consciousness of where their homeland is, and that is Cape Breton. Yet, in the context of Canada as a (post)colonial nation-state, Cape Breton is part of "the abducted homelands of our native peoples." The characters' complicity in the displacement involved to claim these lands as homelands troubles the legitimacy of those claims. It is this active position within colonial projects that calls for a new term to define this experience. The concept of the settled diaspora serves to recognize the attachment to the land that creates a homeland, despite having diasporic origins. Most importantly, it acknowledges that a homeland thus conceived is contested, and that claims to indigeneity within its borders are not fully consistent.

\section{Conclusions}

In terms of migration, diaspora and the recollections and re-enactment of traditions from the homeland, it is clear that these novels present a reading of the hostland that is much deeper and immediate than those they portray of the alleged homelands. Over the course of years and geographical distances, there has been a shift in focus and the characters' identities are no longer primarily attached to the ancestral homelands. Instead, they develop profound affective connections to their present hostlands. While for the first generations of migrants, Nova Scotia must have certainly been an alien space, the gaze of these diasporas is no longer fixed in the loss of the homeland left behind in a distant past, as critical discourses pervasively insist upon. This region is represented as a homeland in the novels, although this is expressed in different ways. Clarke's Africadian novel conveys a relationship to Nova Scotia that is developed through pain, fear and struggle. Clarke emphasizes an imposed legacy of discrimination and explores the very complex roots that tie the Hamiltons to the land, but it is 
particularly through his critical work that the centrality of Nova Scotia as a homeland emerges. No race barriers stop the characters in the Scottish novel from having a fulfilling life in Nova Scotia. Alterity is incorporated to the story through both Celtic ethnicity and certain class divisions that obstruct the social mobility of some of the characters. Besides, those who escape those limitations, like the narrator, are compelled to feel guilty about it. However, the novel portrays deep connections to the land, memories of places and transcendental passages of interaction with the landscapes which result in the, overall, unmistakable role of Nova Scotia as a homeland. For the characters of both novels, therefore, the homeland is not, as it is for members of traditional diasporas, "a place which is always elsewhere" (Johansen 2008, p. 48). On the contrary, the settled homeland is the present, the "here," even though black communities are ostensibly read as foreigners and class/ethnicity pressures arouse conflicts of repudiation in some of the Scots-Nova Scotian characters.

This analysis has demonstrated that the legacies of the ancestral homeland, while real enough and easy to recognize, do not conform to the ideas of the original land as a space of desired return and true belonging or as object of nostalgia and emotional identification. This is one of the main axes that permits the conceptual relocation of the homeland in settled diasporas. However, as the diasporic or foreign origins are not overlooked or erased, nor is the fact that claims to indigeneity need to be carefully scrutinized and contested. Aspects of indigenous identity take on different shapes in these novels. Their characters must confront the presence of Indigenous peoples and their significant relationship to the land as their original homeland of which they are truly native. Clarke's work addresses this tension by aligning with an ancestry that includes the Mi'kmaq, not only at the representational level of the novel, but in the real historical context as well. In No Great Mischief, there is a relative absence of representation of Indigenous peoples. White settler societies are generally constructed upon a sentiment of guilt, and this is often covered by the effacing of the First Nations Peoples' presence in their narratives. Here, feelings of guilt and anxiety over genocide and displacement are subsumed through identification with the margins, but overall, liability and responsibility for violent colonization processes remain largely unacknowledged. Defining this experience as a settled diaspora works to open a conceptual middle ground where it can be framed. It helps to illustrate how a certain group relates to a certain locality that becomes a homeland after prolonged contact but where indigeneity cannot be unequivocally invoked on account of that group's migrant origins and that locality's colonization histories. The concept of the settled diaspora carefully distinguishes this group from Indigenous identities, whose origins are not to be found elsewhere. However, it seems fit to emphasize here once more that diasporas are not superseded by the settled diaspora experience, which forestalls naming these phenomena "postdiasporas," a term that seems to be more accessible and more easily transmittable but which nevertheless implies a chronological and/or ontological progression. The nuances of settled diasporas are to be found in dialogical relationships both with traditional conceptions of the diaspora and with indigenous identities.

Funding: This research was supported by the Spanish National R\&D Programme, project RTI2018-097186-B-I00 (Strangers and cosmopolitans: alternative worlds in contemporary literatures) financed by MCIU/AEI/FEDER, EU, and by the R\&D Programme of the Principado de Asturias, through the Research Group Intersections (grant number GRUPIN IDI/2018/000167).

Conflicts of Interest: The author declares no conflict of interest.

\section{References}

Alfred, Taiaiake. 2015. Cultural Strength: Restoring the Place of Indigenous Knowledge in Practice and Policy. Australian Aboriginal Studies 1: 3-11.

Amadahy, Zainab, and Bonita Lawrence. 2009. Indigenous Peoples and Black People in Canada: Settlers or Allies? In Breaching the Colonial Contract: Anti-Colonialism in the US and Canada. Edited by Arlo Kempf. Dordrecht: Springer, pp. 105-36.

Brah, Avtar. 1996. Cartographies of Diaspora: Contesting Identities. London and New York: Routledge.

Brubaker, Rogers. 2005. The "diaspora” Diaspora. Ethnic and Racial Studies 28: 1-19. [CrossRef] 
Byrd, Jodi. 2011. The Transit of Empire: Indigenous Critiques of Colonialism. Minneapolis: University of Minnesota Press.

Calloway, Colin. 2008. White People, Indians, and Highlanders: Tribal Peoples and Colonial Encounters in Scotland and America. Oxford: Oxford University Press.

Clarke, George E. 1991. Fire on the Water: An Anthology of Black Nova Scotian Writing, Volume One. Porters Lake: Pottersfield Press.

Clarke, George E. 2002. Odysseys Home: Mapping African-Canadian Literature. Toronto: University of Toronto Press.

Clarke, George E. 2006. George and Rue. London: Vintage.

Clarke, George E. 2012. “Indigenous Blacks": An Irreconcilable Identity? In Cultivating Canada: Reconciliation through the Lens of Cultural Diversity. Edited by Ashok Mathur, Jonathan Dewar and Mike DeGagné. Ottawa: Aboriginal Healing Foundation, pp. 399-406.

Clifford, James. 1994. Diasporas. Cultural Anthropology 9: 302-38. [CrossRef]

Cohen, Robin. 2008. Global Diasporas: An Introduction, 2nd ed. New York: Routledge.

Coleman, Daniel. 2016. Indigenous Place and Diaspora Space: Of Literalism and Abstraction. Settler Colonial Studies 6: 61-76. [CrossRef]

Compton, Anne, and George Elliott Clarke. 1998. Standing Your Ground: George Elliott Clarke in Conversation. Studies in Canadian Literature 23: 139-65.

Cornellier, Bruno. 2016. Interculturalism, Settler Colonialism, and the Contest over "Nativeness". In Biopolitics and Memory in Postcolonial Literature and Culture. Edited by Michael Griffiths. London: Routledge, pp. 77-99.

Coulthard, Glen Sean. 2014. Red Skin, White Masks: Rejecting the Colonial Politics of Recognition. Minneapolis: University of Minnesota Press.

Devine, Tom M. 2011. To the Ends of the Earth: Scotland's Global Diaspora 1750-2010. London: Penguin.

Gilroy, Paul. 1993. The Black Atlantic: Modernity and Double Consciousness. London and New York: Verso.

Herrero, Dolores. 2014. Crossing the Secret River: From Victim to Perpetrator, or the Silent/Dark Side of the Australian Settlement. Atlantis 36: 87-105.

Hiscock, Andrew. 2000. "This Inherited Life": Alistair MacLeod and the Ends of History. The Journal of Commonwealth Literature 35: 51-70.

Johansen, Emily. 2008. "Streets Are the Dwelling Place of the Collective" Public Space and Cosmopolitan Citizenship in Dionne Brand's What We All Long For. Canadian Literature 196: 48-62.

Keefer, Janice K. 1987. Under Eastern Eyes: A Critical Reading of Maritime Fiction. Toronto: University of Toronto Press. Kyser, Kristina, and George Elliott Clarke. 2007. George and Ruth: An Interview with George Elliott Clarke about Writing and Ethics. University of Toronto Quarterly 76: 861-73. [CrossRef]

MacLeod, Alistair. 2000. No Great Mischief. London: Vintage.

MacLeod, Alexander. 2008. "The Little State of Africadia Is a Community of Believers": Replacing the Regional and Remaking the Real in the Work of George Elliott Clarke. Studies in Canadian Literature/Étude en Litterérature Canadienne 33: 96-114.

Madden, Paula. 2009. African Nova Scotian-Mi'kmaw Relations. Black Point: Fernwood.

Mills-Proctor, Dorothy. 2010. Born Again Indian: A Story of Self Discovery of a Red-Black Woman and Her People. Kola 22: 44-137.

Poliandri, Simone. 2011. First Nations, Identity, and Reserve Life: The Mi'kmaq of Nova Scotia. Nebraska: University of Nebraska Press.

Reid, John G. 2009. Empire, the Maritime Colonies, and the Supplanting of Mi'kma'ki/Wulstukwik, 1780-1820. Acadiensis 38: 78-97.

Reis, Michele. 2004. Theorizing Diaspora: Perspectives on "Classical” and "Contemporary" Diaspora. International Migration 42: 41-60. [CrossRef]

Rodríguez, Carla. 2007. Polémicas sobre la aplicación de las teorías postcoloniales en Escocia. BABEL-AFIAL 16: 65-85.

Rushdie, Salman. 1992. Imaginary Homelands: Essays and Criticism, 1981-1991. London: Granta Books, in Association with Penguin Books.

Schoene, Berthold. 1995. A Passage to Scotland: Scottish Literature and the British Postcolonial Condition. Scotlands 2: 107-22. 
Smithers, Gregory. 2014. Introduction: “What Is an Indian?"-The Enduring Question of American Indian Identity. In Native Diasporas: Indigenous Identities and Settler Colonialism in the Americas. Edited by Gregory Smithers and Brooke Newman. Lincoln: University of Nebraska Press, pp. 13-24.

Tölölyan, Khachig. 1996. Rethinking Diaspora(s): Stateless Power in the Transnational Moment. Diaspora 5: 3-36. [CrossRef]

Tuan, Yi-Fu. 1977. Space and Place: The Perspective of Experience. Minneapolis: University of Minnesota Press.

Urquhart, Jane. 2001. The Vision of Alistair MacLeod. In Alistair MacLeod: Essays on His Works. Edited by Irene Guilford. Toronto: Guernica, pp. 36-42.

Vance, Michael. 2005. Powerful Pathos: The Triumph of Scottishness in Nova Scotia. In Transatlantic Scots. Edited by Celeste Ray. Tuscaloosa: University of Alabama Press, pp. 156-79.

Zhang, Benzi. 2000. Identity in Diaspora and Diaspora in Writing: The Poetics of Cultural Transrelation. Journal of Intercultural Studies 21: 125-42. [CrossRef]

(C) 2020 by the author. Licensee MDPI, Basel, Switzerland. This article is an open access article distributed under the terms and conditions of the Creative Commons Attribution (CC BY) license (http://creativecommons.org/licenses/by/4.0/). 